\title{
DOES CORPORATE GOVERNANCE MATTER IN BANKING SECTOR SOUNDNESS? (AN EMPIRICAL STUDY ON UZBEKISTAN)
}

\author{
Ulugbek Atamuratov, Graduate School of Economics, Ritsumeikan University, Japan \\ Hiroshi Izawa, Graduate School of Economics, Ritsumeikan University, Japan
}

dx.doi.org/10.18374/JIFE-20-1.4

\begin{abstract}
In the last two decades, corporate governance issues have become the most popular research areas in the global financial system due to the worldwide financial crises. During these periods, Uzbekistan has also paid more attention for corporate governance issues in the financial sector development by accepting several financial reforms and policies; however, most banks are still underdeveloped in corporate governance practices. Since Uzbekistan's economy is the bank-dominated economy, its development highly relies on the soundness of banking sector. But unfortunately, there is a lack of related academic works and studies to corporate governance issues in banking sector soundness in case of Uzbekistan. For this reason, this paper empirically studies the relationship between corporate governance of banks and banking sector soundness in Uzbekistan through stock market development. In this paper, we employ a multiple regression model with panel data for 29 banks of Uzbekistan over the period of 2003 to 2017. To carry out our investigation, we use the multiple regression model on the natural logarithm of the Z-score to measure the effects of internal and external corporate governance on banking sector soundness in Uzbekistan. The main results of this paper are that internal and external corporate governance do not directly impact on the soundness of the banking sector in both short-run and long-run. More interestingly, external corporate governance along with stock market jointly impacts on the soundness of banking sector for the analyzed period in Uzbekistan. However, internal corporate governance of banks does not fully work in the banking system. To sum up, we find that corporate governance itself is not enough for increasing the soundness of banking sector, stock market development is also considered as a key driver for improving on the soundness of banking sector in Uzbekistan.
\end{abstract}

Keywords: Z-score, banking sector soundness, corporate governance, stock market, Uzbekistan 